Documento de Trabajo 2012-03

Facultad de Economía y Empresa

Universidad de Zaragoza

Depósito Legal Z-1411-2010. ISSN 2171-6668

\title{
IS THERE AN ENVIRONMENTAL KUZNETS CURVE FOR WATER USE? A PANEL SMOOTH TRANSITION REGRESSION APPROACH
}

\begin{abstract}
Rosa Duarte $^{\text {a) }}$, Vicente Pinilla ${ }^{\text {b) }}$ and Ana Serrano ${ }^{\text {c)* }}$
${ }^{a}$ Department of Economic Analysis, Faculty of Economics and Business Studies, Universidad de Zaragoza, Gran Vía 2, 50005 Zaragoza, Spain, rduarte@unizar.es

b) Department of Applied Economics and Economic History, Faculty of Economics and Business Studies, Universidad de Zaragoza, Gran Vía 2, 50005 Zaragoza, Spain, vpinilla@unizar.es

${ }^{c}$ Department of Economic Analysis, Faculty of Economics and Business Studies, Universidad de Zaragoza, Gran Vía 2, 50005 Zaragoza, Spain, asergon@unizar.es. Tel: +34 976761786 ext. 4621; fax: +34976761996
\end{abstract}

Abstract: This paper presents an analysis of the relationship between per capita water use and per capita income for 65 countries over the period 1962-2008 within the framework of the so-called environmental Kuznets curve (EKC). Consistent with the existing literature, a polynomial fixed effects model is firstly presented. Then, a logistic Panel Smooth Transition Regression (PSTR) is estimated, capturing individual heterogeneity and time variability of income elasticity. This empirical study yields several important findings. The nexus between water withdrawal per person and per capita GDP is non-linear, showing a peculiar U-inverted with a marked downward limb that dominates the nexus regardless the estimation method chosen. On the whole, water use income elasticity clearly decreases throughout the period; nevertheless it exhibits a great variability over the sample, reflecting the divergent patterns of water use depending on the level of income of each country and period.

Keywords: Water use, Panel Smooth Transition Regression model, Environmental Kuznets Curve, nonlinearity, per capita income.

\footnotetext{
* Corresponding author. Department of Economic Analysis. Faculty of Economics. Gran Vía 2, 50005 Zaragoza (Spain) Tel: 34976762213 Fax:34976761996 e-mail: asergon@unizar.es
} 


\section{IS THERE AN ENVIRONMENTAL KUZNETS CURVE FOR WATER USE? A PANEL SMOOTH TRANSITION REGRESSION APPROACH}

\section{Introduction}

According to WHO/UNICEF (2000), currently more than 2 billion people are concerned by water shortages in over forty countries. Water is one of the most precious resources in the world, which plays a relevant role in economic development. Water is essential for human and ecosystem needs and the availability, use and management of freshwater is vital not only for human welfare, but also for environmental conservation. The limited supply of freshwater, coupled with an exponential growth in demand, seriously threatens the integrity of the natural world as well as the well-being of humanity. Thus, correctly understanding the nexus between water use and per capita income using global data appears to be interesting to identify current trends and foresee future ones; especially in view of the perspectives of international institutions like FAO that states: "by 2025, 1,800 million people will be living in countries or regions with absolute water scarcity, and two-thirds of the world population could be under stress conditions".

The relationship between economic growth and the use of natural resources or emissions has received great attention from the early seventies and the debate continues nowadays. To date, many studies have analyzed environmental pressures from an economic perspective; pointing at population, economic development, urbanization or industrialization as some of the driving forces for natural resources depletion (Nakicenovic et al., 2000; Kander and Lindmark, 2004; WWAP, 2009).

In this general context, the hypothesis of an U-inverted relationship between environmental pressures and economic growth has been put in the foreground. Based on a similar association between the level of inequality and per capita income (Kuznets, 
1955), this relationship was named as the Environmental Kuznets Curve (EKC hereafter). The baseline idea is very simple: At a first stage the greater income is, the higher pressure on natural resources. Then, after reaching an income threshold the trend reverses and the pressure on natural resources tends to decrease. Since the seminal papers of Shafik and Bandyopadhyay (1992), Panayotou, (1993) Selden and Song (1994) and Grossman and Krueger (1995) a lot of research on this topic has been carried out. In all of them the cross-country evidence pointed at an inverted-U curve between pollution indicators and income per capita; nevertheless the turning points are rather divergent. The EKC approach has not already drawn a consistent conclusion and the discussion on its shortcomings still continues these days. On the one hand, the debate focuses on the explanations of the decreasing component (Stern et al., 1996; Ekins, 1997; Roca et al., 2001; Gales et al., 2007; Fouquau et al., 2009). On the other hand, many of the drawbacks refer to econometric issues such as heterogeneity (Mazzanti and Mussolessi, 2010; Vollebergh et al. , 2009), functional form or spatial dependence (Stern, 2004; Aslanidis, 2009).

On the whole, most research on the EKC deals with pollutant emissions and energy. However, there are few studies examining the link between water resources and per capita income. The lack of consistent data or the relative abundance of water in developed countries, among other causes, left the water resources evaluation from a similar perspective out. The few works on this topic, (Cole, 2004; Katz, 2008) study the cross-country or panel-data evidence using polynomial models and seem to be consistent with the existence of an EKC for water use. These models present, however, two major drawbacks. Firstly, they use limited global datasets with few observations; what could reduce the precision for the estimates that reflect the variability not only 
among individuals, but also among temporal periods. Secondly, the use of polynomial panel data models assuming that elasticity depends indirectly on income, across the $\mathrm{N}$ countries and the $\mathrm{T}$ periods of the sample, seems to be quite restrictive. In our opinion, an econometric method that allows the parameters to change smoothly appears to be more accurate to capture the heterogeneous behavior of countries whose actions are not identical and follow a slow pace, as can be expected in the case of water uses.

Therefore, the main purpose of this article is to empirically study the nexus between per capita income and water withdrawal. From a theoretical point of view, the increase in water use during the first stages of economic development would be due to the rise of food of high income elasticity, that in general are more water intensive, industrialization and water requirements of their activities as well as urbanization processes and the development of running water systems. Since agriculture has been, and still is, the main water consumer, particularly important is the expansion of irrigation that took place in many places to enable the increase in production. The possible fall in per capita water use would be related to technological developments, that particularly in agriculture have generated more efficient irrigation systems, to structural change owing to the share increase of activities with low water intensity, such as industry or services, and the setup of specific policies that look for an increase in efficiency in view of scarcity problems (Duarte et al., 2011). It seems reasonable to think that countries in process of development have taken advantage of technological advances that save water in the last decades and thus could require less water per person that pioneering countries in industrialization and modern economic growth (Dasgupta et al., 2002). Obviously a country water use do not only depends on income but also on their climatic conditions and water management. To take into account these other factors we must add two 
control variables. The first one, precipitations, is used as a proxy for water availability. The second one, political freedom, tries to measure the quality of institutions.

For our empirical strategy we will use the traditional the traditional panel data models together with the Panel Smooth Transition Regression (PSTR, hereafter) approach. PSTR models, opposite to polynomial models, have the advantages of providing the water-income nexus with more flexibility, capturing cross-country heterogeneity and time variability. To this end, we use a logistic PSTR model with per capita income as a threshold variable, which allows the "income-water withdrawal" link to be influenced by a transition variable, that is, per capita income. Besides, PSTR models are quite innovative and some empirical applications have been recently published (Chang et al., 2011; Lee and Chiu, 2011; Chiu, 2012).

This methodology is applied to a water use balanced panel of 65 countries over the years 1960-2008. In our view, the contribution of this article is twofold. Firstly as far as we know, this kind of model is used to explore the "water use-income" nexus for the first time, contributing to literature on the relationship of the use of water resources and GDP per capita. Moreover, the use of a larger dataset than in the few previous works could provide a better overview of the interactions between these two variables, being a step forward in the analysis of the relationships between economic growth and the use of water resources. Secondly, unlike previous studies on the same topic, the PSTR provides a quantification of the "water use-income" relationship depending on the country and temporal period, since elasticities can be obtained as a weighted average of the estimates. That way, it is possible to examine the different water use patterns according to the level of development of each cross-section; adopting a temporal 
perspective which is really important to understand the historical influence of income on water use.

Although water use is found to increase for the lowest values of per capita income, our findings seem to globally point at a negative association between per capita income and per capita water withdrawal, regardless the model used. Our results say that there exists a particular EKC with a decreasing limb that dominates the link between these two variables from 1960 to nowadays; nonetheless, these data should be put in perspective, trying to link them with the little information available for the first half of the twentieth century. A polynomial and PSTR models are estimated; nevertheless the second ones are preferred by linearity tests, since they captures heterogeneity and non linearities in the dataset. The estimated elasticities show the great variability of the data; finding different country individual patterns. The least developed countries in the sample show positive elasticities that tend to increase until 1995, when this trend reverses. Emerging countries, like China, display decreasing elasticities, from positive to negative values. Finally the richest countries in the dataset exhibit negative elasticities that seem to decrease throughout the period, although at a slower pace during the last decades. Nevertheless, it will be necessary to examine these results in a broader temporal framework. Eventually, we add two control variables to the polynomial and the PSTR models. The first one, precipitations, is used as a proxy for water availability. The second one, political freedom, tries to measure the quality of institutions. Both of them appear as significant to explain water use per person and have the expected sign.

The remainder of the article proceeds as follows. The next section introduces the methodology describing the PSTR model, the specification and the estimation 
procedures. Section three describes the data and presents the empirical results. In section four a discussion of the results is presented. Finally section five concludes.

\section{Methodology}

\subsection{The PSTR model}

Traditional literature on the EKC commonly uses polynomial models, which basically consist of estimating the well-known fixed effects model by ordinary least squares (Cole, 2004; Katz, 2008). Apart from the polynomial estimation; in this paper we adopt a PSTR model. Extension of panel threshold regressions (Hansen, 1999), the PSTR was first applied by González et al. (2005) to examine the effect of capital market imperfections on investment. This methodology has been commonly used in finance (Chang et al., 2011) and recently, in environmental economics (Aslanidis and Xepapadeas, 2006; Lee and Chiu, 2011; Chiu, 2012). However water issues have not been studied from this perspective. After estimating a PSTR model for the relationship of income with energy intensity and electricity consumption, respectively, Destais et al. (2007) and Bessec and Fouquau (2008) summarize the three main advantages of this type of models. Firstly, they capture the heterogeneity in the dataset, since it allows for a smooth transition between the extreme regimes. In the second place, the threshold value is not given a priori, but it is calculated in the model. Finally, they offer a parametric method to examine the individual heterogeneity and time variability of income elasticity. In addition, as income is also added as explanatory variable, its impact on water use is easy to measure. Therefore, capturing nonlinearities and regime switching, makes the PSTR a good tool for the study of the "per capita income-water use relationship".

The simplest model with individual-fixed effects is defined as follows: 


$$
\begin{gathered}
W_{i t}=\mu_{i}+\beta_{1} Y_{i t}+\beta_{2} Y_{i t} g\left(Y_{i t} ; \gamma, c\right)+\varepsilon_{i t} \\
i=1, \ldots, N t=1, \ldots, T
\end{gathered}
$$

where $W_{i t}$ is the logarithm of per capita water withdrawal in country $i$ in year $t, Y_{i t}$ is the logarithm of per capita income in country $i$ in year $t, \mu_{i}$ are the country specific effects and $\varepsilon_{i t}$ is an error term. The transition function $g\left(Y_{i t} ; \gamma, c\right)$ is a continuous function of $Y_{i t}$ bounded between 0 and 1, consequently there are a continuum of states between those two extreme regimes.

Following the work of González et al. (2005) and Colletaz and Hurlin(2006) who also try to check the EKC hypothesis, the transition function is formulated as follows:

$$
g\left(Y_{i t} ; \gamma, c\right)=\left(1+\exp \left(-\gamma\left(Y_{i t}-c\right)\right)\right)^{-1} \quad \gamma>0
$$

where c denotes the location parameter or the threshold between the two extreme regimes and $\gamma$ determines de smoothness of the transition. In order to analyse the nonlinear link between GDP per capita and water use per person, the transition variable is assumed to be the logarithm of per capita income in country $i$ in year $t$. When $\gamma$ tends to infinity, the transition between the extreme regimes is sharp and the PSTR becomes a panel threshold model (Hansen, 1999). If on the contrary $\gamma$ tends to zero, the transition function $g\left(Y_{i t} ; \gamma, c\right)$ is constant and the model collapses into a standard lineal model with country specific effects.

In the context of the "income-water use relationship", income elasticity is obtained as a weighted average of $\beta_{1}$ and $\beta_{2}$.

$$
e_{i t}^{P S T R}=\frac{\partial W_{i t}}{\partial Y_{i t}}=\beta_{1}+\beta_{2} g\left(Y_{i t} ; \gamma, c\right)+\beta_{2} Y_{i t} \frac{\partial g\left(Y_{i t} ; \gamma, c\right)}{\partial Y_{i t}}
$$


As a consequence, when examining the vector $\beta_{1}$ and $\beta_{2}$ we can only interpret the sign of the parameters that mean an increase or a decrease in per capita water withdrawal with per capita income, being necessary to calculate water income elasticities to quantify the relative increase or decrease per unit of income.

Eventually, it is noteworthy that the smooth transition regression is a more general specification of the quadratic polynomial model commonly used to study the EKC. As a result, according to Aslanidis and Xepapadeas (2006), using regime switching models like the PSTR is justified by the fact that polynomial models, usually utilized to test the existence of the EKC, are particular cases of the PSTR.

\subsection{Estimation and linearity tests}

Before estimating the PSTR it is important to test whether the regime switching effect is statically significant. Testing linearity in equation 1 can be done by testing $H_{0}: \gamma=0$ or $H_{0}: \beta_{1}=\beta_{2}$. In both cases, the test will be non-standard, because under $H_{0}$ the model contains unidentified nuisance parameters. In the framework of the PSTR, the solution offered is similar to the one proposed by Luukkonen et al. (1988) for the so-called Davies problem in time series (Davies, 1977, 1987). It consists of approximating the transition function $g\left(Y_{i t} ; \gamma, c\right)$ using the first and second Taylor expansion around $\gamma=0$. Then, an equivalent hypothesis in an auxiliary regression is tested (see Aslanidis and Xepapadeas (2006) for more detail). We then obtain:

$$
\begin{aligned}
& W_{i t}=\mu_{i}+\theta_{1} Y_{i t}+\theta_{2} Y_{\mathrm{it}}^{2}+\varepsilon_{\mathrm{it}}^{*} \\
& W_{i t}=\mu_{i}+\theta_{1} Y_{i t}+\theta_{2} \mathrm{Y}_{\mathrm{it}}^{2}+\theta_{3} \mathrm{Y}_{\mathrm{it}}^{3}+\varepsilon_{\mathrm{it}}^{*}
\end{aligned}
$$

Therefore, testing linearity is equivalent to testing $H_{0}: \theta_{2}=0$ in equation 4 and $H_{0}: \theta_{2}=\theta_{3}=0$ in equation 5. If $S S R_{0}$ equals the sum of squared residuals under 
$H_{0}$ (lineal panel model with individual fixed effects) and $S S R_{1}$ is the sum of squared residuals under $H_{1}$ (PSTR model with two extreme regimes), the F statistic turns out to be:

$$
L M_{F}=\left(S S R_{0}-S S R_{1}\right) /\left[S S R_{0} /(T N-N-1)\right]
$$

Once we have tested linearity, we proceed with the estimation of the PSTR in equation 1. It consists of two steps. Firstly, fixed effects are eliminated by removing individual-specific means. Taking individual means in equation 1 yields:

$$
\overline{\mathrm{W}}_{i}=\mu_{i}+\beta_{1} \overline{\mathrm{Y}}_{i}+\beta_{2} \overline{\mathrm{W}}_{1}(\gamma, c)+\bar{\varepsilon}_{i}
$$

Where $\quad \bar{W}_{l}, \quad \bar{Y}_{l}, \quad \overline{\mathrm{W}}_{1}(\gamma, c)$ and $\bar{\varepsilon}_{i}$ are individual means with $\overline{\mathrm{W}}_{1}(\gamma, c)=\frac{1}{T} \sum_{t=1}^{T} Y_{i t} g\left(Y_{i t} ; \gamma, c\right)$. Removing equation 7 from equation 1 we obtain:

$$
\widetilde{\mathrm{W}}_{\mathrm{it}}=\beta^{\prime} \widetilde{\mathrm{Y}}_{\mathrm{it}}(\gamma, c)+\tilde{\varepsilon}_{i t}
$$

Thus, the transformed element $\widetilde{\mathrm{Y}}_{\mathrm{it}}(\gamma, c)=\left(Y_{i t}-\overline{\mathrm{Y}}_{i}, Y_{i t} g\left(Y_{i t} ; \gamma, c\right)-\overline{\mathrm{W}}_{\mathrm{l}}(\gamma, c)\right)$ depends on the parameters of the transition function $\gamma$ and $c$ through both the levels and state means. So the vector $\widetilde{Y}_{i t}(\gamma, c)$ has to be recomputed at each iteration. Given a couple $(\gamma, c)$ obtained from a grid search, $\beta_{1}$ and $\beta_{2}$ are estimated by ordinary least squares conditioned on the values of $\gamma$ and $c$. Then, in the second step, parameters $\gamma$ and $c$ are estimated by Non Linear Least Squares (NLS).

An important issue to take into account is the selection of starting values of $\gamma$ and $\mathrm{c}$, since it notably determines the convergence procedure. To select good starting values, a two-dimensional grid search of 50 values for $\gamma$ and 100 values of $\mathrm{c}$ is carried out. Given these grids, the vector with the minimum residual sum of squares is used to estimate the corresponding $\beta_{1}$ and $\beta_{2}$. 
After estimating, the next phase consists of testing the number of transition functions that must be included in the specification. Thus, we will test the null hypothesis that there is 1 transition function versus the alternative there are 2 transition functions.

$$
\begin{aligned}
& W_{i t}=\mu_{i}+\theta_{1} Y_{i t}+\theta_{2} Y_{i t} g\left(Y_{i t} ; \gamma, c\right)+\theta_{3} Y_{\mathrm{it}}^{2}+\varepsilon_{\mathrm{it}}^{*} \\
& W_{i t}=\mu_{i}+\theta_{1} Y_{i t}+\theta_{2} Y_{i t} g\left(Y_{i t} ; \gamma, c\right)+\theta_{3} Y_{\mathrm{it}}^{2}+\theta_{4} \mathrm{Y}_{\mathrm{it}}^{3}+\varepsilon_{\mathrm{it}}^{*}
\end{aligned}
$$

In this case, the null hypothesis will be $H_{0}: \theta_{3}=0$ in equation 9 and $H_{0}: \theta_{3}=\theta_{4}=0$ in equation 10. This recursive procedure continues until $H_{0}$ is not rejected.

Subsequently,, we apply the instrumental variable extension of the PSTR model (IV-PSTR) proposed by Fouquau et al. (2008) and Lee and Chiu (2011). Following Lee and Chiu (2012) we will take the lagged value of the explanatory variable as instrumental variable, $Z_{i t}=Y_{i t-1} . \quad$ Then, $\tilde{Z}_{i t}(\gamma, c)=\left(Z_{i t}-\bar{Z}_{i}, g\left(Y_{i t} ; \gamma, c\right)-\right.$ $\bar{\zeta}(\gamma, c))$, where $\bar{Z}_{i}=\frac{\sum_{t=1}^{T} Z_{i t}}{T}$ and $\bar{\zeta}(\gamma, c)=\frac{\sum_{t=1}^{T} Z_{i t} g\left(Y_{i t} ; \gamma ; c\right)}{T}$. As before, $\tilde{Z}_{i t}(\gamma, c)$ and $\widetilde{\mathrm{Y}}_{\mathrm{it}}(\gamma, c)$ have to be recalculated at each iteration. Consequently, given $(\gamma, c)$ the parameters will be obtained by instrumental variables as follows:

$$
\begin{aligned}
& \hat{\beta}_{I V}(\gamma, c)= \\
& =\left[\sum_{i=1}^{N} \sum_{t=1}^{T} \tilde{Y}_{i t}^{\prime}(\gamma, c) \tilde{Z}_{i t}(\gamma, c)\left(\tilde{Z}_{i t}^{\prime}(\gamma, c) \tilde{Z}_{i t}(\gamma, c)\right)^{-1} \tilde{Z}_{i t}^{\prime}(\gamma, c) \tilde{Y}_{i t}(\gamma, c)\right] \\
& \times\left[\sum_{i=1}^{N} \sum_{t=1}^{T} \tilde{Y}_{i t}^{\prime}(\gamma, c) \tilde{Z}_{i t}(\gamma, c)\left(\tilde{Z}_{i t}^{\prime}(\gamma, c) \tilde{Z}_{i t}(\gamma, c)\right)^{-1} \tilde{Z}_{i t}^{\prime}(\gamma, c) \tilde{Y}_{i t} \widetilde{W}_{i t}\right]
\end{aligned}
$$


Then, during the second stage, the parameters of the transition function $\gamma$ and $\mathrm{c}$ are estimated by Non Linear Least Squares conditionally to $\hat{\beta}_{I V}(\gamma, c)$.

So far, our model only examines the effect that income per person exerts on the dependent variable, keeping all other factors determining per capita water withdrawal constant. However, there are many other elements influencing per capita water use. Thus, in order to reduce the possible omission variable bias, as well as quantifying some of the factors affecting per capita water use, we add two control variables. The first one, the annual average precipitation volume (precipitation) is used as a proxy for water availability. As water scarcity is usually a regional problem, we aim to capture climatic regional differences, particularly as far as water resources are concerned. The introduction of this variable is justified by the fact that those areas with greater water scarcity tend to use their resources in a more efficient way (Gleick, 2000). Thus, the variable precipitation is expected to show a positive sign. Secondly, some authors focus on the differences in environmental management depending on political and social conditions in different countries. Some of them argue that an improvement in democracy entails a development of environmental performance and consequently a lower level of natural resources use and environmental damage (Wislow, 2005; Li and Revenue, 2006). For that reason, we try to control for institutional differences by adding a variable called political freedom $(\mathrm{PF})$. On the basis of the information provided by Freedom House, we use this qualitative variable ranking from 1 (representing the most political free to 7 the least free). Accordingly, $\mathrm{PF}$ is expected to display a positive coefficient, that is, the higher PF index or the less politically free a country is, the more water per person is withdrawn. Given these control variables the model is written as:

$$
W_{i t}=\mu_{i}+\beta_{1} Y_{i t}+\beta_{2} Y_{i t} g\left(Y_{i t} ; \gamma, c\right)+\beta_{3} \text { Precip }_{i t}+\beta_{4} \mathrm{PF}_{i t}+\varepsilon_{i t}
$$


The variable precipitation is expressed in logarithms, whereas PF is introduced in levels.

\section{Data and Empirical results}

In this study, we use a dataset of water withdrawal in 65 countries over the years 1960, 1970, 1980, 1990, 1995, 2000 and $2008^{1}$. The dataset comes from UNESCO and was prepared for the Comprehensive Assessment of the Freshwater Resources of the World in the framework of the International Hydrological Programme (IHP) of UNESCO. Per capita water use is the ratio of water use to population. Per capita national income is measured by per capita GDP in Geary-Khamis 1990 U.S. \$ on a Purchasing Power Parity basis. Population and per capita income data come from Maddison (2010). Table I reports some descriptive statistics. As can be seen, we have 455 observations for each variable, with per capita income ranging from 217 to 31,177 U.S. \$ of 1990 and a mean of 5,232 U.S. \$ of 1990 and water use per capita between 2.41 and $205,224 \mathrm{Dm}^{3}$ per person. Political Freedom is a variable that assigns a numerical rating from 1 to 7 for both political rights and civil liberties, with 1 representing the most free and 7 the least free. The average of the political rights and civil liberties ratings, known as the freedom rating, determines the overall status: Free (1.0 to 2.5), Partly Free (3.0 to 5.0), or Not Free (5.5 to 7.0) (Freedom House).Precipitations are measured in $10^{9} \mathrm{~m}^{3} /$ year and have a mean of $1303.310^{9}$ $\mathrm{m}^{3} /$ year (AQUASTAT).

\section{Insert table I}

\footnotetext{
1 Although the database provides information for 79 countries, as Hansen (1999) notes, it is unknown if this methodology can be extended to unbalanced panels. In this context, our option is to restrict the sample to 65 countries.
} 
This section displays two kinds of estimations. On the one hand, a polynomial model with fixed effects, as the ones commonly used to examine the EKC, is applied. On the other hand, the PSTR previously explained, will be employed.

Before estimating, it seems convenient to ensure whether our variables have unit roots or not, since to avoid spurious regressions all the variables in the model must be stationary. To this end, we utilize unit root tests for panel data. Table II reports Maddala and Wu's (1999) panel unit root test together with Pesaran's (2007) panel unit root test that accounts for cross sectional dependence in the dataset. The results of table II lead to the rejection of the null hypothesis of a unit root. Consequently, both per capita income and per capita water use are I (0), i.e., our variables do not have a unit root.

\section{Insert table II}

Once the suitability of the variables is tested, we estimate the "water withdrawal-income per capita" relationship using a polynomial panel model (table III) with individual effects and time dummies. It is important to note that both heteroskedasticity and autocorrelation have been detected. Therefore we have applied PCSE, that is to say, we have calculated panel-corrected standard errors (PCSE) and then estimate the following model.

$$
W_{i t}=\mu_{i}+\tau_{\mathrm{t}}+\beta_{1} Y_{i t}+\beta_{2} \mathrm{Y}_{\mathrm{it}}^{2}+\beta_{3} \text { Precip }_{i t}+\beta_{4} \mathrm{PF}_{i t}+\mathrm{u}_{\mathrm{it}}
$$

The coefficient of income appears to be positive and significant at $1 \%$. This parameter is high and superior to 1 . In the second place, the parameter of income squared is clearly negative and again significant at $1 \%$. In this case, its value is small, reaching -0.09 . According to these results, water use seems to follow a growing trend with a steep slope for low income values. As income rises, the slope turns gentler until an income per 
person of 818 U.S. \$, from that moment, a continuous fall can be seen. Precipitation shows positive elasticity, indicating that the higher water endowment a country has, the more water per person is used. Moreover, PF coefficient is 0.723 , meaning that when the political freedom index increases (that is, when political freedom falls) per capita water use tends to rise.

\section{Insert table III}

Now let's move to the PSTR model. The first step involves testing whether the regime switching is significant or not. If linearity is rejected, then we have to determine the number of transition functions to capture all the heterogeneity. In table IV we can see the F-statistics and p-values of the tests of linearity versus PSTR, as well as of the non remaining linearity. The linearity test leads to the rejection of the linear "per capita water use - income per person" relationship. In addition, we can conclude that a model with only a transition function is enough to capture the non linear behavior of the data, since the hypothesis of two regimes (one optimal transition function) is not rejected.

\section{Insert table IV}

\section{Insert table $\mathbf{V}$}

Therefore, a PSTR model with one transition function seems to be appropriate to capture the heterogeneity of the data. Table V shows the estimated models (model 1 to model 3) with individual fixed effects that capture country specific features such as climate or water endowments and with temporal dummies to control for time varying aspects like exogenous technological development, productive structure, or consumer 
society $^{2}$. Table V also includes t-ratios corrected for heteroskedasticity. Recall that only the signs of the estimated parameters Income $\left(\beta_{1}\right)$ and Income as transition variable $\left(\beta_{2}\right)$ can be interpreted, whereas both the sign and the value of precipitation $\left(\beta_{3}\right)$ and PF make sense $\left(\beta_{4}\right)$. From table $V$ we observe that income coefficient $\left(\beta_{1}\right)$ is always significant positive, whereas the parameter of the transition variable $\left(\beta_{2}\right)$ is always negative, and higher than $\beta_{1}$ in absolute value. This simply means that, for low income values, when the threshold variable (per capita income) grows, the "per capita incomeper capita water withdrawal" relationship although positive, tends to decrease. For medium and high incomes the link is negative. The estimation of the slope parameter is small in all the cases, indicating that the transition between the two extreme regimes is not sharp and therefore the "water use-per capita income" relationship cannot be considered as a limited number of regimes but as a continuum of regimes. In sum, we could say that per capita water withdrawal increases with low per capita income. However from a turning point, water withdrawal peaks and the "water use-income" link tends to be negative. This pattern is displayed in figure 1 , where per capita income is plotted against the estimated per capita water use derived from the PSTR model. In this regard, it is important to say that the value of fitted per capita water withdrawal cannot be interpreted, since as we are interested in the association between these two variables, we have omitted fixed effects. In a first step, the increase in income produces a sharp growth in water use, however as countries develop, the more income the less water withdrawal per person. Finally, a deceleration in the de-growth takes place. In this regard, it is important to note that the former does not mean that a real decrease in per

\footnotetext{
${ }^{2}$ Coefficients are positive and increase over time, that is, they show a trend.
} 
capita water use takes place for medium and high GDP values, but that the relationship between per capita income and water use per habitant is negative when all other factors determining water withdrawal per person keep constant. Besides, all countries do not follow exactly the same trajectory, since as stated by De Bruyn et al. (1998), the EKC is a descriptive relationship trying to measure the association between two variables, so, some nations may not follow the estimated pattern and consequently the general turning point may not match up with the actual of individual countries.

As we said before, to improve the possible omission variable bias we have estimated PSTR controlling for availability of water resources and for the quality of institution (model 3). From table $\mathrm{V}$ we can see how the estimates of income $\beta_{1}$ and income as transition variable $\beta_{2}$ are rather similar in the three models presented. Moreover, as expected sign of the parameter precipitations $\beta_{3}$ is positive, indicating that a $1 \%$ increase in annual average level of precipitation involves a $5.02 \%$ rise in per capita water use. Likewise, as previously indicated the parameter $\beta_{4}$ associated with political freedom equals 0.74 . This shows that a higher political freedom index (i.e., less political freedom) implies more per capita water use, in other words, an increase in democracy entails less use of water resources per person.

\section{Insert figure 1}

\section{Insert figure 2}

Figure 2 illustrates the scattered graph of the logistic transition function against per capita income. There are only few observations within the low extreme regime $g\left(Y_{i t} ; \gamma, c\right)=0$ and no observations within the upper extreme regime $\left.g\left(Y_{i t} ; \gamma, c\right)=1\right)$. 
Nonetheless, the transition phase contains most of the data, what clearly displays the large heterogeneity on the sample and again reminds the need of using the PSTR model.

In sum, estimates reach the same general conclusion; there exists a positive link between per capita water withdrawal and per capita income for low income levels. From this threshold, the impact of per capita income on water use per person is significantly negative, that is, a rise in per capita income involves a drop in the quantity of water used per person all other things being equal or held constant. Nevertheless, as we will see later (figure 4), on average, the value of income elasticity is somehow divergent, depending on the model chosen (quadratic or PSTR).

Once we have estimated the parameters, it is possible to obtain the time varying individual income elasticity of water use for each country and period. Equation 3 gives the formula to calculate income elasticity of the PSTR model. The elasticity of a homogeneous quadratic polynomial model is given by the expression:

$$
e_{i t}^{\text {quadratic }}=\frac{\partial W_{i t}}{\partial Y_{i t}}=\beta_{1}+\beta_{2} Y_{i t}
$$

Therefore, income elasticity varies depending on both the year and the country in the PSTR model and quadratic polynomial model. However, it is important to take into account that this fact is due to different reasons. As we can see in (14), income elasticity in the quadratic fixed effects regression depends on the value of the parameters $\beta_{1}$ and $\beta_{2}$ as well as on the value of per capita income. That is, as the estimated $\beta$ are common for all countries and periods in this model, the individual and time variability of $e_{i t}$ quadratic will be determined by per capita GDP. On the contrary, if we examine $e_{i t}{ }^{\text {PSTR }}$ (equation 3), apart from income, the variability in elasticity stems from the transition function. Figure 3 reports the link between per capita income and the 
PSTR income elasticity. The association is clearly non-linear, more concretely, elasticity appears to be inversely correlated with per capita GDP; nonetheless, this decreasing trend tends to steady for the highest income observations.

\section{Insert figure 3}

Income elasticity is time varying, so table VI reports the individual average elasticities based on the historical values of per capita income for the polynomial model, the PSTR model, the instrumental variables PSTR model, and the PSTR with control variables. The average standard deviations are also included. The individual average is obtained as follows:

$$
\overline{\mathrm{e}}_{\mathrm{i}=\frac{1}{\mathrm{~T}}} \sum_{\mathrm{t}=1}^{\mathrm{T}} \mathrm{e}_{\mathrm{it}} \quad \mathrm{SE}=\sqrt{\frac{1}{\mathrm{~T}} \sum_{\mathrm{t}=1}^{\mathrm{T}}\left(\mathrm{e}_{\mathrm{it}}-\overline{\mathrm{e}}_{\mathrm{i}}\right)^{2}}
$$

\section{Insert table VI}

In general, the PSTR and quadratic elasticities tend to be quite similar in most cases (quadratic polynomial elasticities are slightly higher), what could bear out that the PSTR is a good approximation of the quadratic fixed effects model. However, as linearity was rejected in table IV, we find that the PSTR is the optimal model to account for the heterogeneity in the data, and therefore, in the following we will focus on the values of the former estimates.

On the whole, there seem to be significant differences among countries. Looking at table VI, we observe that the average income elasticities of water use are rather diverse. For example, in the PSTR model, the estimated values range from -0.59 of United States to 0.07 of Zaire, what clearly illustrates the great heterogeneity of the sample. On global average, water use income elasticity is -0.24 . The countries that are 
below average have the highest per capita income levels and belong mainly to North America (Canada or EE.UU.), Oceania and Europe (Sweden or France among others), with no African country in this situation. Many of these developed areas reach elasticity values around -0.6 at the end of the period studied.

The vast majority of nations above average are African or Asian and its mean income is less than 3,029 1990 U.S. \$. In this heterogeneous group it is possible to find different patterns. On the one hand, countries such as India or China that in 1960 displayed positive elasticities, have followed a decreasing trend and exhibit negative values around -0.3 nowadays. On the other hand, we find states like Madagascar or Haiti that have adopted the opposite pattern, from negative to positive elasticities. Finally, those with the lowest income (from Bangladesh to Zaire) are outstanding, since they display positive elasticities during all the period, that is, from 1960 to 2008 the relationship between water withdrawal and income is direct and even growing in places like Zaire.

As well as taking into account heterogeneity, one of the key points of the PSTR model is that it allows examining temporal dynamics of the dataset. Thus, in order to analyze trends in the water use-income link, the global average of the results obtained in polynomial, PSTR, IV-PSTR and PSTR control estimates are plotted in figure 4. As shown in figure 4, the income elasticity of water use is, on global average, negative and decreasing. The global path is clear, there is a continuous decrease of income elasticity from 1960, i.e., the "income-water withdrawal" relationship is negative, and tends to decrease with time. On global average, the reduction in income elasticity is particularly intense from 1960 to 1980 , given that from this moment the reduction continues but at a slower pace. It is also noteworthy the fact that on average PSTR, IV-PSTR and PSTR 
control elasticities are very close; nevertheless, and in spite of following a similar path, the polynomial elasticity is rather divergent in value.

\section{Insert figure 4}

\section{Discussion}

Several recent papers (Kander et al., 2004; Gales et al., 2007) carry out the assessment of the EKC in a long run framework, giving a historical and crompenhensive overview of the relationship between economic growth and environmental impacts or energy consumption. In our case, it is not possible to obtain data prior to 1960 for a wide set of countries. Nonetheless, it seems viable to put in context our results with the trajectory of global water use, or some regional groups, from 1900.

\section{Insert figure 5}

Figure 5 plots a curve with a sharp upward limb between 1900 and 1960, a slower growth until 1980 and a smooth fall from this moment. A less aggregate analysis by continents (table VII), confirms, broadly speaking, this result; clearly corroborating the decrease in per capita water use from 1980 to 1990 in all of them and the previous growth.

\section{Insert table VII}

All these data would suggest the existence of a rising limb for low income values. That is, if we had individual data for the whole $\mathrm{XX}^{\text {th }}$ century and we could analyze the link between per capita income and per capita water use graphically as seen in figure 5, it would be possible to distinguish a lengthy and steep growing trend and a 
small and smooth falling limb. Thus, the gradual growth of the first half of the twentieth century would dominate the association and we could probably assert the presence of a more complete EKC. Nevertheless, such a statement is not possible based on our estimates from 1960.

Accordingly, at the lowest levels of per capita income, more income seems to boost water use. As said by Goklany (2002), in this step the highest priority consists of meeting basic needs without paying attention to environmental damage. In the particular case of water resources, per capita income affects freshwater use from different perspectives. First of all, improvements in standards of living entail changes in dietary patterns, moving towards more water intensive goods such as meat or fruit, what is possible due to the extension of irrigation and the construction of water infrastructure. In addition, the development of the industrial sector together with the growing urbanization, imply a great and diverse increase in per capita water use (Duarte et al., 2011).

As per capita GDP increases, water use income elasticity turns out to be negative, i.e., more affluence means less water withdrawal per habitant. According to Duarte et al. (2011), the combination of technical, managerial and institutional developments, improve the efficiency of water use. We could point at advances in environmental regulation, the perception of health risks, improvements of irrigation systems or economic constraints, among other factors. We concur with Stern (2004) who, when talking about emissions, says that innovations are adopted in high-income countries first and with a shot lag before they are implemented in many emerging countries, allowing emission drops in both developed and developing countries at the same time. Therefore, improvements such as micro irrigation or water pricing seem to 
be put in practice first in developed areas and subsequently transferred to countries with less per capita GDP, giving place to substantial reductions or stabilizations in water use per capita, in both developed and developing areas. That way, countries such as Mexico, Malaysia or Poland, among others, show similar negative elasticities values in 2008 to the ones of developed countries like France, United States or Australia in 1960. In this regard, we should consider the temporal framework we are working with; if data for the whole twentieth century were available our results would probably change. That is, as we said before the growing trend of the link would be steeper and developing countries could not have taken advantage of technological advances taken place in developed areas from the seventies. Consequently, as the growing limb would dominate the curve, the least developed countries would reach negative elasticity at higher income levels. Finally, the areas with highest GDP per capita also show negative elasticities, however as these countries become wealthier, the decrease produced in water use due to an increase of per capita GDP tends to be smaller. Measures like the Clean Water Act in the United States or the introduction of new irrigation techniques had an important initial impact, leading a notable decrease in water use; nonetheless their original effect appears to flatten as time goes by. Despite this fact, some authors like Gleick and Palaniappan (2010) refer to the concept of peak water, meaning that some developed countries, like for instance the United States, have little leeway for the expansion of water withdrawal. Mainly, they refer to agriculture, responsible for around $80 \%$ of global water use, and say that it appears difficult a greater enlargement of agriculture in high-income countries, particularly in arid areas, where water resources and land are no longer available or their use appears to be ecologically and economically unsustainable. Therefore, following this reasoning, we could say that although the fall in water use levels out in the majority of developed countries, some factors seem to indicate that it is unlikely that per capita water use rises sharply again. 


\section{Conclusion}

In this paper we have assessed the "water use-income" relationship (in per capita terms) in 65 countries from 1960. To that aim, we have estimated different models; a quadratic polynomial fixed effects model, a Panel Smooth Transition Regression, the late Panel Smooth Transition Regression with lagged per capita income as an instrument and a Panel Smooth Transition Regression with control variables. The four of them lead to a similar conclusion, what corroborates the robustness of the results. Firstly, there exists a non-linear link between per capita water use and income. When plotting these two variables, they seem to represent a peculiar inverted-U shape, i.e., water use tends to increase with the lowest income observations but this trend reverses when income becomes greater, being the downward limb prevailing. As far as this relationship is concerned, it is important to highlight that a negative link between per capita income and water use per person does not mean that the per capita use of water resources decreases, but that the more income per capita the less use of water resources keeping the other factors influencing water use constant. Moreover, the value of the smoothness parameter indicates that the transition is slow. Secondly, the variability in income elasticity of water use reflects the large heterogeneity in the sample. Elasticity is positive when income is low and negative as income grows. Eventually, if we look at the global trajectory of income elasticity, there is no doubt that it decreases as time goes on. This fall is particularly sharp until the eighties but tends to be flatter for the highest income levels. The volume of water resources of a country (precipitations used as a proxy) is positively significant to explain per capita water use; therefore, those countries with water scarcity tend to be more efficient and use less water per person. 
Eventually, higher levels of democracy appear to trigger better environmental institutions and thus, less water use per capita.

As a result, is there an Environmental Kuznets Curve for water use? Following Kander and Lindmark (2004), who offer an EKC examination in the long run and taking into account the great increase seen for per capita water use during the first half of the twentieth century, together with the previous estimates which show a negative water use-income link, it would be possible to distinguish an upward and a downward limb. However, the results of this study, with information from 1960, only allow us to state that there exists a peculiar EKC with a marked falling trend that dominates the link. As seen in Duarte et al. (2011), at the same time economic development entailed pressures on water resources, technological innovations and institutional changes were introduced in both, developed and emerging nations, making up for income increases. In this respect, it is important to note that although an increase in water use (in absolute terms) can be observed for the vast majority of areas, representing a growing pressure on the resource, our findings appear to suggest a negative link between per capita GDP and per capita water withdrawal keeping all other factors constant. In this sense, the trajectory of variables such as population or technology, among others, could be decisive to explain the trend followed by water withdrawal seen in Duarte et al. (2011). Obviously, despite innovations have been adopted in developing countries with relatively short lags regarding most developed areas; there is still a lot to do, since it exists a wide margin of action around key issues such as water pricing or water metering, particularly in agriculture. These aspects have a crucial nature for the continuation of the decreasing path of the "per capita water use - per capita income" nexus, because, as we have 
previously seen, the decline in income elasticity keeps becoming smoother as income grows and the pressure on the resource is increasing in many areas of the world.

\section{Acknowledgements}

This work is partially supported by a doctoral grant from the Government of Spain (A. Serrano) and by the Ministry of Science and Innovation of the Spanish Government, projects ECO2009-07796 (V. Pinilla) and ECO2010-14929 (R. Duarte and A.Serrano) and the Department of Science, Technology and Universities of the Government of Aragon, Research Excellence Group for 'Agri-food Economic History' (V.Pinilla) and Research Consolidated Group "Growth, Demand and Natural Resources" (R. Duarte and A. Serrano).

\section{References}

AQUASTAT database, Food and Agriculture Organization of the United Nations (FAO). Website accessed on [16/05/2012]

Aslanidis, N., 2009. Environmental Kuznets Curves for carbon emissions: A critical survey. Fondazione Eni Enrico Mattei 75.

Aslanidis, N., Xepapadeas, A., 2006. Smooth transition pollution-income paths. Ecological Economics 57, 182-189.

Bessec, M., Fouquau, J., 2008. The non-linear link between electricity consumption and temperature in Europe: A threshold panel approach. Energy Economics 30, 2705-2721.

Carter, S.B., 2006. Historical statistics of the United States : earliest times to the present. Cambridge University Press, New York. 
Chang, T., Chiang, G., 2011. Regime-switching effects of debt on real GDP per capita the case of Latin American and Caribbean countries. Economic Modelling 28, 24042408.

Chiu, Y.-B., 2012. Deforestation and the Environmental Kuznets Curve in Developing Countries: A Panel Smooth Transition Regression Approach. Canadian Journal of Agricultural Economics/Revue canadienne d'agroeconomie 60, 177-194.

Cole, M.A., 2004. Economic growth and water use. Applied Economics Letters 11, 1 4.

Colletaz, G., Hurlin, C., 2006. Threshold Effects of the Public Capital Productivity : An International Panel Smooth Transition Approach. University of Orleans.

Dasgupta, S., Laplante, B., Wang, H., Wheeler, D., 2002. Confronting the Environmental Kuznets Curve. Journal of Economic Perspectives 16, 147-168.

Davies, R.B., 1977. Hypothesis testing when a nuisance parameter is present only under the alternative. Biometrika 64, 247-254.

Davies, R.B., 1987. Hypothesis testing when a nuisance parameter is present only under the alternative. Biometrika 74, 33-43.

De Bruyn, S. M., Van Den Bergh, J. C. J. M. and Opschoor, J. B., 1998. Economic growth and emissions: reconsidering the empirical basis of environmental Kuznets curves. Ecological Economics 25, 161-175.

Destais, G., Fouquau, J., Hurlin, C., 2007. Economic Development and Energy Intensity: a Panel Data Analysis, in: Girod, J., Bourbonnais, R., Keppler, J.H. (Eds.), The Econometrics of Energy Systems. Palgrave Macmillan.

Duarte, R., Pinilla, V., Serrano, A., 2011. Looking backward to look forward: water use and economic growth from a long-term perspective. Asociación Española de Historia Económica. 
Ekins, P., 1997. The Kuznets curve for the environment and economic growth: Examining the evidence. Environment and Planning A 29, 805-830.

Fouquau, J., Destais, G., Hurlin, C., 2009. Energy demand models: a threshold panel specification of the 'Kuznets curve'. Applied Economics Letters 16, 1241 - 1244. Fouquau, J., Hurlin, C., Rabaud, I., 2008. The Feldstein Horioka puzzle: A panel smooth transition regression approach. Economic Modelling 25, 284-299.

www.freedomhouse.org . Website accessed on [16/05/2012]

Gales, B., Kander, A., Malanima, P., Rubio, M., 2007. North versus South: Energy transition and energy intensity in Europe over 200 years. European Review of Economic History 11, 219-253.

Geological Survey, U.S., Estimated use of water in the United States. U.S. Dept. of the Interior, U.S. Geological Survey, Washington, D.C.

Gleick, P. H. 2000. The changing water paradigm - A look at twenty-first century water resources development. Water International 25(1): 127-138.

Gleick, P. H. and Palaniappan, M.,2010. Peak water limits to freshwater withdrawal and use. Proceedings of the National Academy of Sciences 107, 11155-11162.

Goklany, I.M., 2002. Comparing 20th century trends in US and Global agricultural water and land use. Water International 27, 321-329.

González, A., Terasvirta, T., Dijk, D.v., 2005. Panel Smooth Transition Regression Models. Quantitative Finance Research Centre, University of Technology, Sydney. 
Grossman, G.M., Krueger, A.B., 1995. Economic-Growth and the Environment. Quarterly Journal of Economics 110, 353-377.

Hansen, B.E., 1999. Threshold effects in non-dynamic panels: Estimation, testing, and inference. Journal of Econometrics 93, 345-368.

Kander, A., Lindmark, M., 2004. Energy consumption, pollutant emissions and growth in the long run: Sweden through 200 years. European Review of Economic History 8, 297-335.

Katz, D.L., 2008. Water, Economic Growth, and Conflict: Three Studies. University of Michigan

Kuznets, S., 1955. Economic Growth and Income Inequality. American Economic Review 65, 1-28.

Lee, C.-C., Chiu, Y.-B., 2011. Electricity demand elasticities and temperature: Evidence from panel smooth transition regression with instrumental variable approach. Energy Economics 33, 896-902.

Lee, C.-C., Chiu, Y.-B., 2012. The impact of real income on insurance premiums: Evidence from panel data. International Review of Economics and Finance 21, 246-260. Li, Q. and Reuveny, R. 2006. Democracy and Environmental Degradation, International Studies Quarterly 50(4): 935-956.

Luukkonen, R., Saikkonen, P., Teräsvirta, T., 1988. Testing Linearity Against Smooth Transition Autoregressive Models. Biometrika 75, 491-499.

Maddala, G.S., Wu, S., 1999. A Comparative Study of Unit Root Tests with Panel Data and a New Simple Test. Oxford Bulletin of Economics and Statistics 61, 631-652. 
Maddison, A., 2010. Statistics on World Population, GDP and Per Capita GDP, 1-2008

Mazzanti, M. and Musolesi, A., 2010. Carbon Abatement Leaders and Laggards Non Parametric Analyses of Policy Oriented Kuznets Curves. Note di lavoro Fondazione Eni Enrico Mattei 149.

Nakicenovic, N., Alcamo, J., Davis, G., Vries, B.d., Fenhann, J., Gaffin, S., Gregory, K., Grübler, A., Jung, T.Y., Kram, T., Rovere, E.L.L., Michaelis, L., Mori, S., Morita, T., Pepper, W., Pitcher, H., Price, L., Riahi, K., Roehrl, A., Rogner, H.-H., Sankovski, A., Schlesinger, M., Shukla, P., Smith, S., Swart, R., Rooijen, S.v., Victor, N., Dadi, Z., 2000. Special Report on Emissions Scenarios, in: Nakicenovic, N., Swart, R. (Eds.), IPCC Special Reports. IPCC.

Panayotou, T., 1993. Empirical Tests and Policy Analysis of Environmental Degradation at Different Stages of Economic Developmeent. Working Paper, Technology and Environment Program, International Labour Office, Geneva.

Pesaran, M.H., Badi, H.B., 2007. Heterogeneity and cross section dependence in panel data models: theory and applications introduction. Journal of Applied Econometrics 22, 229-232.

Roca, J., Padilla, E., Farré, M., Galletto, V., 2001. Economic growth and atmospheric pollution in Spain: discussing the environmental Kuznets curve hypothesis. Ecological Economics 39, 85-99.

Selden, T. M. and Song, D., 1994. Environmental Quality and Development: Is There a Kuznets Curve for Air Pollution Emissions? Journal of Environmental Economics and Management 27(2), 147-162. 
Shafik, N., Bandyopadhyay, S., 1992. Economic Growth and Environmental Quality: Time Series and Cross-Country Evidence. World Bank Policy Research Working Paper WPS 904.

Stern, D.I., 2004. The rise and fall of the environmental Kuznets curve. World Development 32, 1419-1439.

Stern, D.I., Common, M.S., Barbier, E.B., 1996. Economic growth and environmental degradation: The environmental Kuznets curve and sustainable development. World Development 24, 1151-1160.

UNESCO:http://webworld.unesco.org/water/ihp/db/shiklomanov/part\%273/_Read\%27 me.html [last access: March 2011]

Vollebergh, H. R. J., Melenberg, B. and Dijkgraaf, E. 2009. Identifying reduced-form relations with panel data: The case of pollution and income, Journal of Environmental Economics and Management 58(1), 27-42.

WHO, Unicef, 2000. Global water supply and sanitation assessment 2000 report. World Health Organization.

Winslow, M., 2005. Is Democracy Good for the Environment? Journal of Environmental Planning and Management 48, 771-783. 
WWAP., 2009. The United Nations World Water Development Report 3: Water in a Changing World, UNESCO publishing, Paris. 
Table I: Summary statistics

\begin{tabular}{|c|c|c|c|c|}
\hline & Per capita GDP & Per capita water use & Precipitations & Political freedom \\
\hline Mean & 5,232 & 4,796 & 1303 & 3.3 \\
\hline Standard error & 5,652 & 20,675 & 2474 & 1.8 \\
\hline Maximum & 31,177 & 205,224 & 15,174 & 7 \\
\hline Minimum & 217 & 2.4 & 6.1 & 1 \\
\hline Observations & 455 & 455 & 455 & 455 \\
\hline
\end{tabular}

Source: own calculations based on UNESCO

Per capita water use is measured in $\mathrm{Dm}^{3}$ per person.

Per capita GDP in 1990 Dollars per person.

Precipitations are measured in $10^{9} \mathrm{~m}^{3} /$ year. 
DTECONZ 2012-03: R. Duarte, V. Pinilla \& A. Serrano

Table II: Unit Root Tests

Maddala and Wu's (1997) ADF Unit Root Test

\begin{tabular}{lll}
\hline \hline & Per capita GDP & Per capita water use \\
\hline Intercept & $571.4^{* * *}$ & $583.0^{* * *}$ \\
& $(0.0000)$ & $(0.0000)$ \\
Intercept and trend & $190.0^{* * *}$ & $310.9^{* * *}$ \\
& $(0.0005)$ & $(0.0000)$
\end{tabular}

Pesaran ‘s (2007) CIPS Unit Root Test

\begin{tabular}{lll}
\hline \hline & Per capita GDP & Per capita water use \\
\hline Intercept & $-6.972^{* * *}$ & $-7.381^{* * *}$ \\
& $(0.0000)$ & $(0.0000)$ \\
Intercept and trend & $-5.987^{* * *}$ & $-7.145^{* * *}$ \\
& $(0.0005)$ & $(0.0000)$ \\
\hline \hline
\end{tabular}

P-values in parenthesis. ${ }^{* * *} 1 \%$ significant level.

The null hypothesis is that the panel has a unit root 
Table III: Water use-income relationship. Panel model with time and individual fixed effects

Parameters

$\beta_{1}$ Income $\quad 1.245^{* * *} \quad(2.95)$

$\beta_{2}$ :Income squared $\quad-0.0928 * * * \quad(-3.43)$

$\beta_{3}:$ Precipitations $\quad 2.347^{* * *} \quad(5.41)$

$\beta_{4}: \mathrm{PF} \quad 0.7238^{* * *} \quad(5.41)$

Turning point $\quad 818.341990 \$$

The dependent variable is log per capita water use. All variables are in logarithms, except for PF.

Values in parenthesis are t-ratios. ${ }^{* * *}, * *, *$ stand for $1 \%, 5 \%$ and $10 \%$ significant level. 
DTECONZ 2012-03: R. Duarte, V. Pinilla \& A. Serrano

Table IV: Linearity and non remaining heterogeneity tests

\begin{tabular}{llll}
\hline \hline Linearity test vs. PSTR & PSTR & PSTR-IV & PSTR-control \\
& Model(1) & Model $(2)$ & Model(3) \\
\hline$H_{0}: 1$ regime (no transition function) & $\mathrm{F}=12.80766$ & $\mathrm{~F}=12.95102$ & $\mathrm{~F}=13.58784$ \\
$H_{A}: 2$ regimes (1 transition function) & P-value= 3.88815e-04 & P-value= 3.61036e-04 & P-value= 2.59969e-04 \\
\hline No remaining STR-type nonlinearity & & & \\
\hline$H_{0}: 2$ regimes (1 transition function) & $\mathrm{F}=0.01750$ & $\mathrm{~F}=4.92599 \mathrm{e}-04$ & $\mathrm{~F}=0.00642$ \\
$H_{A}: 3$ regimes (2 transition functions) & $\mathrm{P}$-value $=0.89483$ & $\mathrm{P}$-value $=0.98230$ & $\mathrm{P}$-value $=0.93620$ \\
\hline \hline
\end{tabular}

Statistics are reported until the non rejection of $H_{0}$ 
Table V: Parameter estimation of the PSTR

\begin{tabular}{|c|c|c|c|}
\hline Variables & $\begin{array}{l}\text { PSTR } \\
\text { Model(1) }\end{array}$ & $\begin{array}{l}\text { PSTR-IV } \\
\text { Model(2) }\end{array}$ & $\begin{array}{l}\text { PSTR-control } \\
\text { Model(3) }\end{array}$ \\
\hline $\mathrm{B}_{1}$ :Income & $\begin{array}{l}0.314^{* *} \\
(1.99)\end{array}$ & $\begin{array}{l}0.3698^{* *} \\
(2.169)\end{array}$ & $\begin{array}{l}0.346^{* *} \\
(2.13)\end{array}$ \\
\hline $\mathrm{B}_{2}:$ Income & $-0.595 * * *$ & $-0.678 * * *$ & $-0.785^{* * *}$ \\
\hline Transition variable & $(-3.39)$ & $(-3.46)$ & $(-3.50)$ \\
\hline $\mathrm{B}_{3}:$ Precipitacion & & & $\begin{array}{l}5.02 * * * \\
(3.66)\end{array}$ \\
\hline $\mathrm{B}_{4}: \mathrm{PF}$ & & & $\begin{array}{l}0.742^{* * *} \\
(5.58)\end{array}$ \\
\hline C & $\begin{array}{l}10.53 \\
\text { (antilog 37,697.10) }\end{array}$ & $\begin{array}{l}10.64 \\
\text { (antilog 42,048.65) }\end{array}$ & $\begin{array}{l}11.42 \\
\text { (antilog 91,126.26) }\end{array}$ \\
\hline 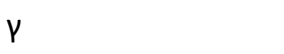 & 0.45 & 0.414 & 0.382 \\
\hline RSS & 39.898 & 39.858 & 39.426 \\
\hline AIC & -2.39001 & -2.39099 & -2.39312 \\
\hline $\mathrm{BIC}$ & -2.29945 & -2.3044 & -2.28445 \\
\hline
\end{tabular}

Values in parenthesis are t-ratios.

$* *, * * *$ stand for $5 \%$ and $1 \%$ significant level.

Standard errors corrected for heterokedasticity. 
DTECONZ 2012-03: R. Duarte, V. Pinilla \& A. Serrano

Table VI: Individual average of income elasticity of water use 


\begin{tabular}{|c|c|c|c|c|c|c|c|c|c|}
\hline & \multirow{2}{*}{$\begin{array}{l}\text { Average GDP p.c. } \\
(\$ 1990)\end{array}$} & \multicolumn{2}{|c|}{ Quadratic } & \multicolumn{2}{|l|}{ PSTR } & \multicolumn{2}{|c|}{ IV PSTR } & \multicolumn{2}{|c|}{ PSTR control } \\
\hline & & $\bar{e}_{i t}$ & $\bar{\sigma}$ & $\bar{e}_{i t}$ & $\bar{\sigma}$ & $\bar{e}_{i t}$ & $\bar{\sigma}$ & $\bar{e}_{i t}$ & $\bar{\sigma}$ \\
\hline Afghanistan & 660.5 & 0.03 & 0.03 & 0.02 & 0.02 & 0.03 & 0.03 & 0.02 & 0.02 \\
\hline Albania & $2,366.1$ & -0.18 & 0.06 & -0.18 & 0.06 & -0.18 & 0.06 & -0.18 & 0.06 \\
\hline Algeria & $2,743.5$ & -0.21 & 0.03 & -0.21 & 0.03 & -0.21 & 0.03 & -0.21 & 0.03 \\
\hline Argentina & 7,707.9 & -0.39 & 0.04 & -0.41 & 0.04 & -0.41 & 0.04 & -0.41 & 0.05 \\
\hline Australia & $16,042.6$ & -0.51 & 0.06 & -0.55 & 0.07 & -0.55 & 0.07 & -0.57 & 0.08 \\
\hline Bangladesh & 695.1 & 0.03 & 0.04 & 0.01 & 0.04 & 0.02 & 0.04 & 0.01 & 0.04 \\
\hline Bolivia & 2,316.9 & -0.18 & 0.03 & -0.18 & 0.03 & -0.18 & 0.04 & -0.18 & 0.03 \\
\hline Brazil & $4,447.1$ & -0.29 & 0.06 & -0.30 & 0.07 & -0.30 & 0.07 & -0.30 & 0.07 \\
\hline Burkina Faso & 797.9 & 0.00 & 0.03 & 0.00 & 0.02 & 0.00 & 0.03 & -0.01 & 0.02 \\
\hline Canada & $16,630.6$ & -0.52 & 0.06 & -0.56 & 0.07 & -0.56 & 0.07 & -0.58 & 0.08 \\
\hline Colombia & $4,307.0$ & -0.29 & 0.06 & -0.29 & 0.06 & -0.29 & 0.06 & -0.30 & 0.06 \\
\hline Costa Rica & $4,836.8$ & -0.31 & 0.06 & -0.32 & 0.07 & -0.32 & 0.07 & -0.32 & 0.07 \\
\hline Cuba & $2,457.7$ & -0.19 & 0.04 & -0.19 & 0.05 & -0.19 & 0.05 & -0.19 & 0.05 \\
\hline Chad & 482.0 & 0.09 & 0.04 & 0.06 & 0.03 & 0.07 & 0.03 & 0.06 & 0.03 \\
\hline Chile & $7,186.8$ & -0.37 & 0.07 & -0.40 & 0.08 & -0.40 & 0.08 & -0.40 & 0.09 \\
\hline China & $1,824.4$ & -0.14 & 0.15 & -0.14 & 0.15 & -0.14 & 0.15 & -0.15 & 0.15 \\
\hline Dominican Republic & $2,445.5$ & -0.19 & 0.07 & -0.19 & 0.08 & -0.19 & 0.08 & -0.19 & 0.08 \\
\hline Ecuador & $3,442.7$ & -0.25 & 0.04 & -0.25 & 0.04 & -0.25 & 0.04 & -0.25 & 0.04 \\
\hline Egypt & $2,094.4$ & -0.16 & 0.08 & -0.16 & 0.08 & -0.16 & 0.08 & -0.16 & 0.08 \\
\hline El Salvador & $2,347.3$ & -0.18 & 0.03 & -0.18 & 0.03 & -0.18 & 0.03 & -0.18 & 0.03 \\
\hline France & $15,153.7$ & -0.50 & 0.07 & -0.54 & 0.07 & -0.54 & 0.07 & -0.56 & 0.08 \\
\hline Guatemala & $3,394.8$ & -0.25 & 0.04 & -0.25 & 0.05 & -0.25 & 0.05 & -0.25 & 0.05 \\
\hline Haiti & 900.5 & -0.02 & 0.04 & -0.02 & 0.03 & -0.02 & 0.03 & -0.02 & 0.03 \\
\hline Honduras & $1,835.4$ & -0.14 & 0.03 & -0.13 & 0.03 & -0.13 & 0.03 & -0.14 & 0.03 \\
\hline India & $1,320.8$ & -0.08 & 0.08 & -0.08 & 0.08 & -0.08 & 0.08 & -0.08 & 0.08 \\
\hline Indonesia & $2,230.5$ & -0.17 & 0.10 & -0.17 & 0.10 & -0.17 & 0.10 & -0.17 & 0.10 \\
\hline Israel & $11,282.4$ & -0.45 & 0.08 & -0.48 & 0.09 & -0.49 & 0.09 & -0.50 & 0.10 \\
\hline Italy & $13,440.1$ & -0.48 & 0.07 & -0.52 & 0.08 & -0.52 & 0.09 & -0.53 & 0.09 \\
\hline
\end{tabular}




\begin{tabular}{|c|c|c|c|c|c|c|c|c|}
\hline Jamaica & $3,484.2$ & -0.25 & 0.02 & -0.25 & 0.03 & -0.25 & 0.03 & -0.25 \\
\hline Japan & $13,739.1$ & -0.49 & 0.11 & -0.52 & 0.12 & -0.52 & 0.12 & -0.54 \\
\hline Jordan & $3,684.9$ & -0.26 & 0.06 & -0.26 & 0.06 & -0.26 & 0.06 & -0.26 \\
\hline Lebanon & $3,029.0$ & -0.23 & 0.05 & -0.23 & 0.05 & -0.23 & 0.05 & -0.23 \\
\hline Liberia & $1,123.3$ & -0.06 & 0.03 & -0.05 & 0.03 & -0.05 & 0.03 & -0.06 \\
\hline Madagascar & 874.8 & -0.01 & 0.04 & -0.02 & 0.04 & -0.01 & 0.04 & -0.02 \\
\hline Malaysia & $4,478.3$ & -0.29 & 0.12 & -0.31 & 0.14 & -0.30 & 0.14 & -0.31 \\
\hline Mali & 752.2 & 0.01 & 0.04 & 0.00 & 0.04 & 0.01 & 0.04 & 0.00 \\
\hline Mauritania & 981.4 & -0.03 & 0.04 & -0.03 & 0.03 & -0.03 & 0.03 & -0.04 \\
\hline Mexico & $5,642.0$ & -0.33 & 0.05 & -0.35 & 0.06 & -0.35 & 0.06 & -0.35 \\
\hline Morocco & $2,241.7$ & -0.17 & 0.06 & -0.17 & 0.06 & -0.17 & 0.06 & -0.17 \\
\hline New Zealand & $13,480.5$ & -0.48 & 0.04 & -0.52 & 0.04 & -0.52 & 0.04 & -0.53 \\
\hline Nicaragua & $1,784.7$ & -0.14 & 0.05 & -0.13 & 0.05 & -0.13 & 0.05 & -0.13 \\
\hline Niger & 614.0 & 0.05 & 0.04 & 0.03 & 0.03 & 0.04 & 0.04 & 0.03 \\
\hline Nigeria & $1,143.7$ & -0.06 & 0.03 & -0.06 & 0.03 & -0.05 & 0.03 & -0.06 \\
\hline Panama & $4,564.2$ & -0.30 & 0.06 & -0.31 & 0.07 & -0.31 & 0.07 & -0.31 \\
\hline Peru & $3,770.6$ & -0.26 & 0.04 & -0.27 & 0.04 & -0.27 & 0.04 & -0.27 \\
\hline Philippines & 2,143.1 & -0.17 & 0.04 & -0.16 & 0.04 & -0.16 & 0.04 & -0.16 \\
\hline Poland & $5,608.3$ & -0.33 & 0.06 & -0.35 & 0.07 & -0.35 & 0.07 & -0.35 \\
\hline Portugal & $8,518.5$ & -0.40 & 0.10 & -0.43 & 0.11 & -0.43 & 0.11 & -0.44 \\
\hline Saudi Arabia & $7,800.9$ & -0.39 & 0.06 & -0.41 & 0.07 & -0.41 & 0.08 & -0.42 \\
\hline Senegal & 1,328.8 & -0.09 & 0.01 & -0.08 & 0.01 & -0.08 & 0.01 & -0.08 \\
\hline South Africa & $3,912.8$ & -0.27 & 0.02 & -0.28 & 0.03 & -0.28 & 0.03 & -0.28 \\
\hline Spain & $9,779.1$ & -0.43 & 0.11 & -0.46 & 0.12 & -0.46 & 0.12 & -0.47 \\
\hline Sudan & 967.8 & -0.03 & 0.04 & -0.03 & 0.04 & -0.03 & 0.04 & -0.03 \\
\hline Sweden & $16,026.5$ & -0.51 & 0.06 & -0.55 & 0.06 & -0.55 & 0.06 & -0.57 \\
\hline Syria & $5,613.9$ & -0.33 & 0.07 & -0.35 & 0.08 & -0.35 & 0.08 & -0.35 \\
\hline Tanzania & 559.5 & 0.06 & 0.03 & 0.04 & 0.02 & 0.05 & 0.02 & 0.04 \\
\hline Thailand & $3,608.3$ & -0.26 & 0.13 & -0.27 & 0.15 & -0.26 & 0.15 & -0.27 \\
\hline Trinidad \& Tobago & $10,509.1$ & -0.44 & 0.07 & -0.47 & 0.07 & -0.47 & 0.08 & -0.48 \\
\hline
\end{tabular}


DTECONZ 2012-03: R. Duarte, V. Pinilla \& A. Serrano

\begin{tabular}{llllllllll} 
Tunisia & $3,053.4$ & -0.23 & 0.09 & -0.23 & 0.10 & -0.23 & 0.10 & -0.23 & 0.10 \\
Turkey & $4,623.9$ & -0.30 & 0.08 & -0.31 & 0.09 & -0.31 & 0.09 & -0.31 & 0.09 \\
Uruguay & $6,727.8$ & -0.36 & 0.04 & -0.38 & 0.05 & -0.38 & 0.05 & -0.39 & 0.05 \\
USA & $20,660.9$ & -0.56 & 0.06 & -0.59 & 0.06 & -0.60 & 0.07 & -0.62 & 0.08 \\
Vietnam & $1,190.3$ & -0.07 & 0.09 & -0.07 & 0.09 & -0.06 & 0.09 & -0.07 & 0.08 \\
Zaire & 432.2 & & & & & & & & \\
Ex Soviet Union & $5,426.2$ & -0.11 & 0.09 & 0.07 & 0.06 & 0.08 & 0.06 & 0.07 & 0.06 \\
& & -0.33 & 0.05 & -0.34 & 0.05 & -0.34 & 0.06 & -0.34 & 0.06 \\
\hline Total & $3,087.1$ & -0.23 & 0.18 & -0.24 & 0.19 & -0.24 & 0.19 & -0.25 & 0.20 \\
\hline \hline
\end{tabular}

Individual average elasticity and standard deviation (\%) 
DTECONZ 2012-03: R. Duarte, V. Pinilla \& A. Serrano

Table VIII: Per capita water use average anual growth rates (\%)

\begin{tabular}{lllllll}
\hline Region & $\mathbf{1 9 0 0 - 1 9 5 0}$ & $\mathbf{1 9 5 1 - 1 9 6 0}$ & $\mathbf{1 9 6 1 - 1 9 7 0}$ & $\mathbf{1 9 7 1 - 1 9 8 0}$ & $\mathbf{1 9 8 1 - 1 9 9 0}$ & $\mathbf{1 9 9 1 - 2 0 0 0}$ \\
\hline Europe & 2.4 & 4.9 & 1.6 & 2.1 & 1.4 & 1.0 \\
North America & 1.5 & 0.6 & 1.5 & 0.5 & -1.4 & -0.3 \\
Latin America & 0.1 & 1.2 & -0.5 & 0.8 & -0.3 & -0.2 \\
Africa & -0.4 & 2.6 & 0.9 & 0.8 & -0.9 & 1.2 \\
Asia & 0.8 & 1.6 & -0.9 & -0.3 & 0.1 & -0.3 \\
Oceania & 2.8 & 1.4 & 1.6 & 0.5 & 1.0 & -0.2 \\
Ex Soviet Union & 0.8 & 1.1 & 3.5 & 4.5 & 0.2 & -2.1 \\
\hline
\end{tabular}

Source: own calculations based on UNESCO

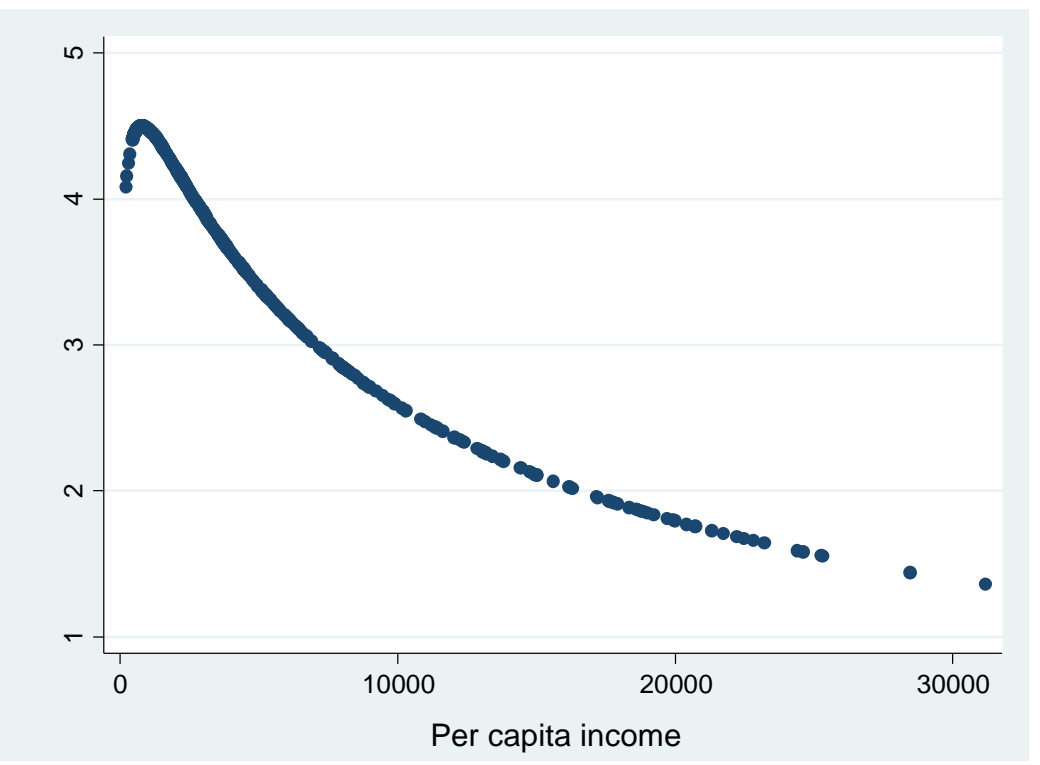

Figure 1: Per capita income vs. fitted per capita water use 


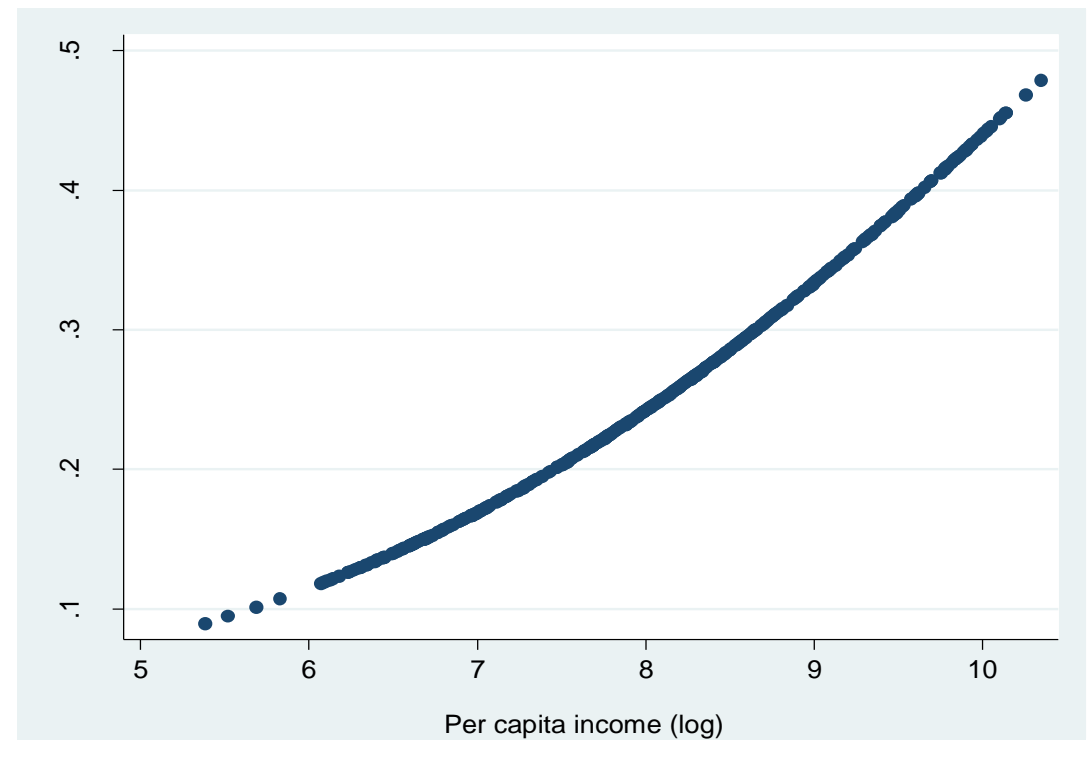

Figure 2: PSTR transition function

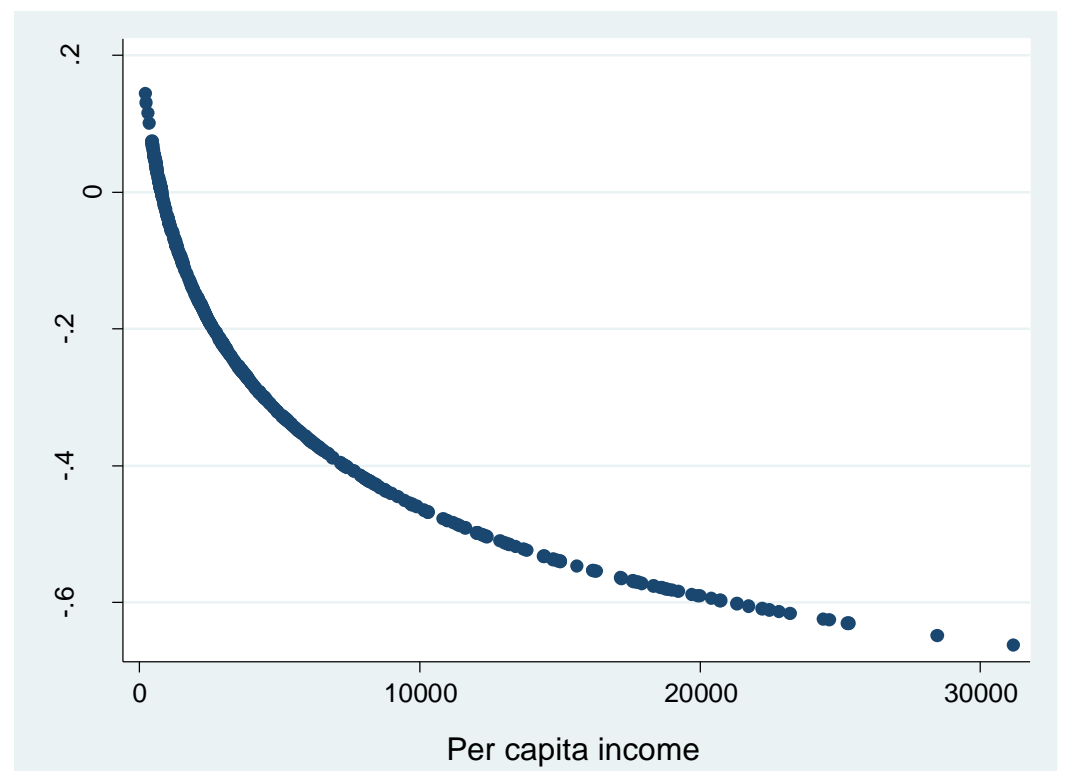

Figure 3: PSTR water use elasticity displayed for all the values of per capita income 


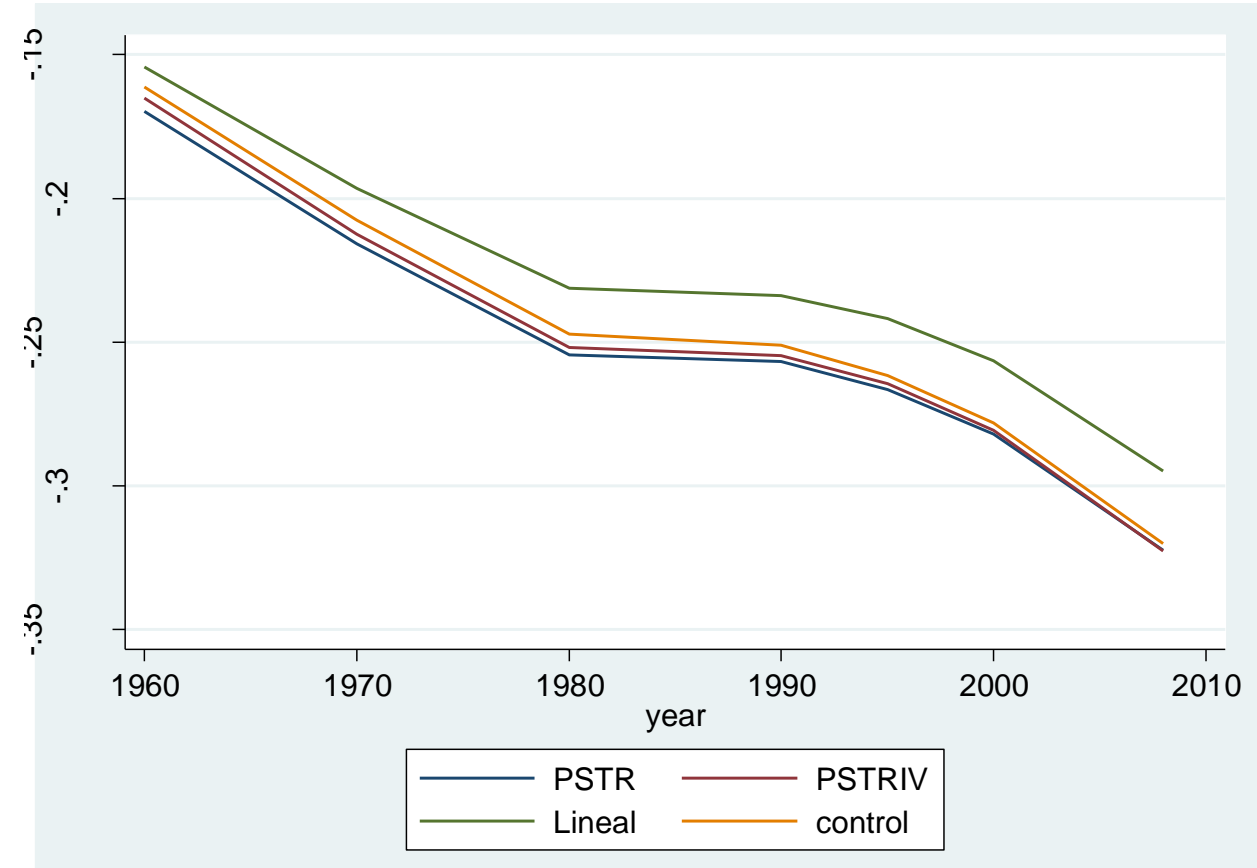

Figure 4: Global time varying elasticities

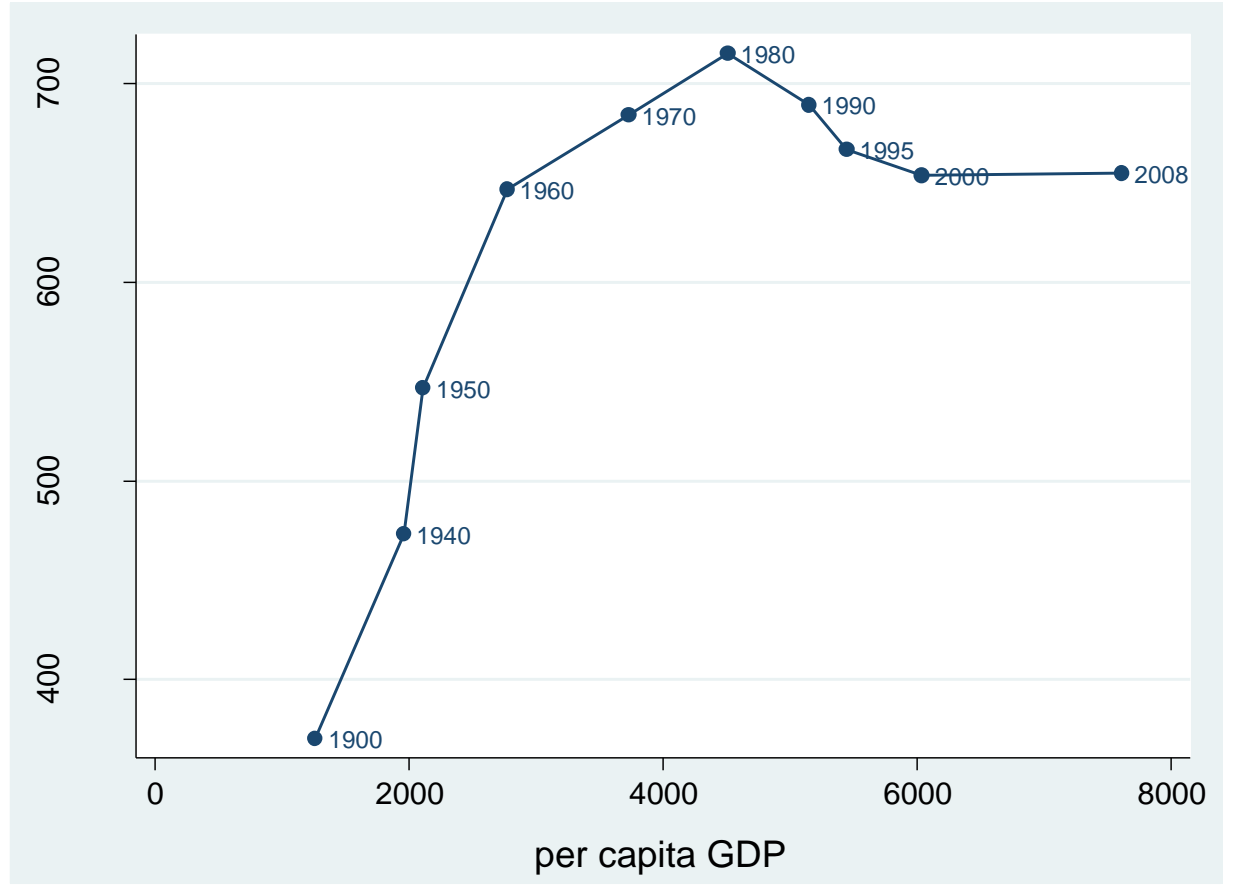

Figure 5: Global average EKC for per capita water use (dm3 yer/per person) 


\section{DOCUMENTOS DE TRABAJO}

Facultad de Economía y Empresa

Universidad de Zaragoza

Depósito Legal Z-1411-2010. ISSN 2171-6668

2002-01: "Evolution of Spanish Urban Structure During the Twentieth Century". Luis Lanaspa, Fernando Pueyo y Fernando Sanz. Department of Economic Analysis, University of Zaragoza.

2002-02: "Una Nueva Perspectiva en la Medición del Capital Humano". Gregorio Giménez y Blanca Simón. Departamento de Estructura, Historia Económica y Economía Pública, Universidad de Zaragoza.

2002-03: "A Practical Evaluation of Employee Productivity Using a Professional Data Base". Raquel Ortega. Department of Business, University of Zaragoza.

2002-04: "La Información Financiera de las Entidades No Lucrativas: Una Perspectiva Internacional". Isabel Brusca y Caridad Martí. Departamento de Contabilidad y Finanzas, Universidad de Zaragoza.

2003-01: "Las Opciones Reales y su Influencia en la Valoración de Empresas". Manuel Espitia y Gema Pastor. Departamento de Economía y Dirección de Empresas, Universidad de Zaragoza.

2003-02: "The Valuation of Earnings Components by the Capital Markets. An International Comparison". Susana Callao, Beatriz Cuellar, José Ignacio Jarne and José Antonio Laínez. Department of Accounting and Finance, University of Zaragoza.

2003-03: "Selection of the Informative Base in ARMA-GARCH Models". Laura Muñoz, Pilar Olave and Manuel Salvador. Department of Statistics Methods, University of Zaragoza.

2003-04: "Structural Change and Productive Blocks in the Spanish Economy: An ImputOutput Analysis for 1980-1994". Julio Sánchez Chóliz and Rosa Duarte. Department of Economic Analysis, University of Zaragoza.

2003-05: "Automatic Monitoring and Intervention in Linear Gaussian State-Space Models: A Bayesian Approach". Manuel Salvador and Pilar Gargallo. Department of Statistics Methods, University of Zaragoza.

2003-06: "An Application of the Data Envelopment Analysis Methodology in the Performance Assessment of the Zaragoza University Departments". Emilio Martín. Department of Accounting and Finance, University of Zaragoza.

2003-07: "Harmonisation at the European Union: a difficult but needed task". Ana Yetano Sánchez. Department of Accounting and Finance, University of Zaragoza. 
2003-08: "The investment activity of spanish firms with tangible and intangible assets". Manuel Espitia and Gema Pastor. Department of Business, University of Zaragoza.

2004-01: "Persistencia en la performance de los fondos de inversión españoles de renta variable nacional (1994-2002)". Luis Ferruz y María S. Vargas. Departamento de Contabilidad y Finanzas, Universidad de Zaragoza.

2004-02: "Calidad institucional y factores político-culturales: un panorama internacional por niveles de renta". José Aixalá, Gema Fabro y Blanca Simón. Departamento de Estructura, Historia Económica y Economía Pública, Universidad de Zaragoza.

2004-03: "La utilización de las nuevas tecnologías en la contratación pública". José $\mathrm{M}^{\mathrm{a}}$ Gimeno Feliú. Departamento de Derecho Público, Universidad de Zaragoza.

2004-04: "Valoración económica y financiera de los trasvases previstos en el Plan Hidrológico Nacional español". Pedro Arrojo Agudo. Departamento de Análisis Económico, Universidad de Zaragoza. Laura Sánchez Gallardo. Fundación Nueva Cultura del Agua.

2004-05: "Impacto de las tecnologías de la información en la productividad de las empresas españolas". Carmen Galve Gorriz y Ana Gargallo Castel. Departamento de Economía y Dirección de Empresas. Universidad de Zaragoza.

2004-06: "National and International Income Dispersión and Aggregate Expenditures". Carmen Fillat. Department of Applied Economics and Economic History, University of Zaragoza. Joseph Francois. Tinbergen Institute Rotterdam and Center for Economic Policy Resarch-CEPR.

2004-07: “Targeted Advertising with Vertically Differentiated Products". Lola Esteban and José M. Hernández. Department of Economic Analysis. University of Zaragoza.

2004-08: "Returns to education and to experience within the EU: are there differences between wage earners and the self-employed?". Inmaculada García Mainar. Department of Economic Analysis. University of Zaragoza. Víctor M. Montuenga Gómez. Department of Business. University of La Rioja

2005-01: "E-government and the transformation of public administrations in EU countries: Beyond NPM or just a second wave of reforms?". Lourdes Torres, Vicente Pina and Sonia Royo. Department of Accounting and Finance.University of Zaragoza

2005-02: "Externalidades tecnológicas internacionales y productividad de la manufactura: un análisis sectorial". Carmen López Pueyo, Jaime Sanau y Sara Barcenilla. Departamento de Economía Aplicada. Universidad de Zaragoza.

2005-03: "Detecting Determinism Using Recurrence Quantification Analysis: Three Test Procedures". María Teresa Aparicio, Eduardo Fernández Pozo and Dulce Saura. Department of Economic Analysis. University of Zaragoza. 
2005-04: "Evaluating Organizational Design Through Efficiency Values: An Application To The Spanish First Division Soccer Teams". Manuel Espitia Escuer and Lucía Isabel García Cebrián. Department of Business. University of Zaragoza.

2005-05: "From Locational Fundamentals to Increasing Returns: The Spatial Concentration of Population in Spain, 1787-2000". María Isabel Ayuda. Department of Economic Analysis. University of Zaragoza. Fernando Collantes and Vicente Pinilla. Department of Applied Economics and Economic History. University of Zaragoza.

2005-06: "Model selection strategies in a spatial context". Jesús Mur and Ana Angulo. Department of Economic Analysis. University of Zaragoza.

2005-07: "Conciertos educativos y selección académica y social del alumnado". María Jesús Mancebón Torrubia. Departamento de Estructura e Historia Económica y Economía Pública. Universidad de Zaragoza. Domingo Pérez Ximénez de Embún. Departamento de Análisis Económico. Universidad de Zaragoza.

2005-08: "Product differentiation in a mixed duopoly". Agustín Gil. Department of Economic Analysis. University of Zaragoza.

2005-09: "Migration dynamics, growth and convergence". Gemma Larramona and Marcos Sanso. Department of Economic Analysis. University of Zaragoza.

2005-10: "Endogenous longevity, biological deterioration and economic growth". Marcos Sanso and Rosa María Aísa. Department of Economic Analysis. University of Zaragoza.

2006-01: "Good or bad? - The influence of FDI on output growth. An industry-level analysis“. Carmen Fillat Castejón. Department of Applied Economics and Economic History. University of Zaragoza. Julia Woerz. The Vienna Institute for International Economic Studies and Tinbergen Institute, Erasmus University Rotterdam.

2006-02: "Performance and capital structure of privatized firms in the European Union". Patricia Bachiller y $\mathrm{M}^{\mathrm{a}}$ José Arcas. Departamento de Contabilidad y Finanzas. Universidad de Zaragoza.

2006-03: "Factors explaining the rating of Microfinance Institutions". Begoña Gutiérrez Nieto and Carlos Serrano Cinca. Department of Accounting and Finance. University of Saragossa, Spain.

2006-04: "Libertad económica y convergencia en argentina: 1875-2000". Isabel Sanz Villarroya. Departamento de Estructura, Historia Económica y Economía Pública. Universidad de Zaragoza. Leandro Prados de la Escosura. Departamento de $\mathrm{H}^{\mathrm{a}}$ e Instituciones Ec. Universidad Carlos III de Madrid.

2006-05: "How Satisfied are Spouses with their Leisure Time? Evidence from Europe*". Inmaculada García, José Alberto Molina y María Navarro. University of Zaragoza. 
2006-06: "Una estimación macroeconómica de los determinantes salariales en España (19802000)". José Aixalá Pastó y Carmen Pelet Redón. Departamento de Estructura, Historia Económica y Economía Pública. Universidad de Zaragoza.

2006-07: "Causes of World Trade Growth in Agricultural and Food Products, 1951 - 2000". Raúl Serrano and Vicente Pinilla. Department of Applied Economics and Economic History, University of Zaragoza, Gran Via 4, 50005 Zaragoza (Spain).

2006-08: "Prioritisation of patients on waiting lists: a community workshop approach". Angelina Lázaro Alquézar. Facultad de Derecho, Facultad de Económicas. University of Zaragoza. Zaragoza, Spain. Begoña Álvarez-Farizo. C.I.T.A.- Unidad de Economía. Zaragoza, Spain

2007-01: "Deteminantes del comportamiento variado del consumidor en el escenario de Compra". Carmén Berné Manero y Noemí Martínez Caraballo. Departamento de Economía y Dirección de Empresas. Universidad de Zaragoza.

2007-02: "Alternative measures for trade restrictiveness. A gravity approach". Carmen Fillat \& Eva Pardos. University of Zaragoza.

2007-03: "Entrepreneurship, Management Services and Economic Growth". Vicente Salas Fumás \& J. Javier Sánchez Asín. Departamento de Economía y Dirección de Empresas. University of Zaragoza.

2007-04: "Equality versus Equity based pay systems and their effects on rational altruism motivation in teams: Wicked masked altruism". Javier García Bernal \& Marisa Ramírez Alerón. University of Zaragoza.

2007-05: "Macroeconomic outcomes and the relative position of Argentina's Economy: 1875-2000". Isabel Sanz Villarroya. University of Zaragoza.

2008-01: "Vertical product differentiation with subcontracting". Joaquín Andaluz Funcia. University of Zaragoza.

2008-02: "The motherwood wage penalty in a mediterranean country: The case of Spain" Jose Alberto Molina Chueca \& Victor Manuel Montuenga Gómez. University of Zaragoza.

2008-03: "Factors influencing e-disclosure in local public administrations". Carlos Serrano Cinca, Mar Rueda Tomás \& Pilar Portillo Tarragona. Departamento de Contabilidad y Finanzas. Universidad de Zaragoza.

2008-04: "La evaluación de la producción científica: hacia un factor de impacto neutral". José María Gómez-Sancho y María Jesús Mancebón-Torrubia. Universidad de Zaragoza.

2008-05: "The single monetary policy and domestic macro-fundamentals: Evidence from Spain“. Michael G. Arghyrou, Cardiff Business School and Maria Dolores Gadea, University of Zaragoza. 
2008-06: "Trade through fdi: investing in services". Carmen Fillat-Castejón, University of Zaragoza, Spain; Joseph F. Francois. University of Linz, Austria; and CEPR, London \& Julia Woerz, The Vienna Institute for International Economic Studies, Austria.

2008-07: "Teoría de crecimiento semi-endógeno vs Teoría de crecimiento completamente endógeno: una valoración sectorial”. Sara Barcenilla Visús, Carmen López Pueyo, Jaime Sanaú. Universidad de Zaragoza.

2008-08: "Beating fiscal dominance. The case of spain, 1874-1998". M. D. Gadea, M. Sabaté \& R. Escario. University of Zaragoza.

2009-01: "Detecting Intentional Herding: What lies beneath intraday data in the Spanish stock market" Blasco, Natividad, Ferreruela, Sandra (Department of Accounting and Finance. University of Zaragoza. Spain); Corredor, Pilar (Department of Business Administration. Public University of Navarre, Spain).

2009-02: "What is driving the increasing presence of citizen participation initiatives?". Ana Yetano, Sonia Royo \& Basilio Acerete. Departamento de Contabilidad y Finanzas. Universidad de Zaragoza.

2009-03: "Estilos de vida y "reflexividad" en el estudio del consumo: algunas propuestas". Pablo García Ruiz. Departamento de Psicología y Sociología. Universidad de Zaragoza.

2009-04: "Sources of Productivity Growth and Convergence in ICT Industries: An Intertemporal Non-parametric Frontier Approach". Carmen López-Pueyo and $\mathbf{M}^{\mathrm{a}}$ Jesús Mancebón Torrubia. Universidad de Zaragoza.

2009-05: "Análisis de los efectos medioambientales en una economía regional: una aplicación para la economía aragonesa”. Mónica Flores García y Alfredo J. Mainar Causapé. Departamento de Economía y Dirección de Empresas. Universidad de Zaragoza.

2009-06: "The relationship between trade openness and public expenditure. The Spanish case, 1960-2000". M Molores Gadea, Marcela Sabate y Estela Saenz. Department of Applied Economics. School of Economics. University of Economics.

2009-07: "Government solvency or just pseudo-sustainability? A long-run multicointegration approach for Spain”. Regina Escario, María Dolores Gadea, Marcela Sabaté. Applied Economics Department. University of Zaragoza.

2010-01: "Una nueva aproximación a la medición de la producción científica en revistas JCR y su aplicación a las universidades públicas españolas”. José María Gómez-Sancho, María Jesús Mancebón Torrubia. Universidad de Zaragoza

2010-02: "Unemployment and Time Use: Evidence from the Spanish Time Use Survey". José Ignacio Gimenez-Nadal, University of Zaragoza, José Alberto Molina, University of Zaragoza and IZA, Raquel Ortega, University of Zaragoza.

2011-01: "Universidad y Desarrollo sostenible. Análisis de la rendición de cuentas de las universidades del G9 desde un enfoque de responsabilidad social”. Dr. José Mariano Moneva y Dr. Emilio Martín Vallespín, Universidad de Zaragoza. 
2011-02: “Análisis Municipal de los Determinantes de la Deforestación en Bolivia.” Javier Aliaga Lordeman, Horacio Villegas Quino, Daniel Leguía (Instituto de Investigaciones SocioEconómicas. Universidad Católica Boliviana), y Jesús Mur (Departamento de Análisis Económico. Universidad de Zaragoza)

2011-03: "Imitations, economic activity and welfare". Gregorio Giménez. Facultad de Ciencias Económicas y Empresariales. Universidad de Zaragoza.

2012-01: "Selection Criteria for Overlapping Binary Models". M. T Aparicio and I. Villanúa. Department of Economic Analysis, Faculty of Economics, University of Zaragoza

2012-02: "Sociedad cooperativa y socio cooperativo: propuesta de sus funciones objetivo". Carmen Marcuello y Pablo Nachar-Calderón. Universidad de Zaragoza

2012-03: "Is there an environmental Kuznets curve for water use? A panel smooth transition regression approach". Rosa Duarte (Department of Economic Analysis), Vicente Pinilla (Department of Applied Economics and Economic History) and Ana Serrano (Department of Economic Analysis). Faculty of Economics and Business Studies, Universidad de Zaragoza 